\title{
Seeking health below the radar: Undocumented People's access to healthcare in two Dutch cities
}

\author{
Helen M. Hintjens ${ }^{\mathrm{a}, *}$, Karin A. Siegmann ${ }^{\mathrm{a}}$, Richard H.J.M. Staring ${ }^{\mathrm{b}}$

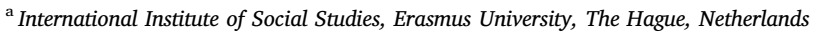 \\ ${ }^{\mathrm{b}}$ School of Law, Erasmus University Rotterdam, Rotterdam, Netherlands
}

\section{Introduction}

Among EU member states, France, the Netherlands and Portugal currently allow undocumented people to access 'normal' healthcare. Most EU countries, like Belgium and Italy allow only emergency healthcare. Formally speaking, under Dutch law, the healthcare provider works within a system that: “... has a very low threshold for access. This is how it should be, since otherwise undocumented patients will not dare to present themselves" (Lampion, 2018: 10). Overall, the Netherlands government adheres to international law in relation to healthcare (Biswas et al., 2012: 54-56), and officially there should be no discrimination, since:

"Dutch law allows no room for service providers to take the migrants' legal status into account when exercising their clinical judgement: care must be 'medically necessary' according to generally accepted professional standards" (Ingleby et al., 2016: 22).

Since 2009, under Article 122a of the Dutch Health Insurance Act, healthcare providers can claim reimbursement for medical costs incurred through medical treatment of 'uninsurable' (i.e. undocumented) patients. Healthcare providers must first seek payment from 'uninsurable' patients (CAK, 2019), and only after they cannot or do not pay, can medical staff and suppliers claim back the costs of medical treatment - 100 per cent is reimbursed for maternity-related treatment, and 80 per cent for all other medical treatment (Ingleby et al., 2016: 21). In March 2018, the CAK or 'central administrative organ' took over this reimbursement scheme, previously managed by the Dutch Healthcare Institute (Zorginstituut Nederland). Apart from this, the scheme remains more or less as it was in 2009 (Lampion, 2018; Ingleby et al., 2016: 21). The problem, however, remains that:

“... undocumented migrants encounter several formal and informal barriers when seeking access to healthcare, including the financial barriers for general access to healthcare services, the reported unwillingness of some healthcare providers to treat undocumented migrants, and the lack of access to acute dental care" (Biswas et al., 2012: 56).
What is clear is that the law is filtered through the lenses of public attitudes, bureaucratic hurdles and the migration policies of government, based on 'deterrence' principles. To realise undocumented people's legal rights to 'medically necessary' health services, perhaps " $(t) h e$ most challenging aspect to influence is ... staff attitudes, which may be linked to personal experiences as much as the wider societal context" (Priebe et al., 2011: 11).

Deficits in provision of gynecological healthcare for women, and mental health for the undocumented generally have been confirmed for adults and children alike (Schoevers, 2011; see also Staring and Aarts, 2010). Even diagnosis and treatment of Tuberculosis (TB) seems to be poor in The Netherlands, despite this disease being a clear public health hazard (Schoevers, 2011).

This study addresses a puzzling problem. Formal legal health rights of 'undocumented' people in The Netherlands are relatively good. Even so, a range of research suggests that significant numbers of undocumented people fail to access healthcare services which they have a right to under Dutch law. In 2012 the Dutch branch of the NGO Médecins du Monde, estimated that almost one third (29\%) of undocumented people in the Netherlands, never received the 'medically necessary' healthcare they were entitled to (in Biswas et al., 2012: 54). A 2013 Ombudsman Report on Asylum Seekers and Failed Asylum Seekers' access to healthcare, found that undocumented people avoided presenting themselves to medical care providers when ill, and tended only to do so in an emergency (De Nationale Ombudsman, 2013).

For undocumented children, Staring and Aarts reported significant numbers of young undocumented people with serious psychological problems, yet not visiting any Dutch healthcare providers (Staring and Aarts, 2010: 161). Although our pilot study excluded those in detention, an excellent study, by Pharos, has documented how difficult failed asylum seekers find it to access the medical care they need, inside Dutch detention centres (Pharos, 2013). Several studies have focused on the supply side of healthcare for undocumented people (see for example Grit et al., 2012; Kulu Glasgow et al., 2000). In contrast, this study sought to find out more about those who did not find their way to healthcare providers, who self-excluded, or who encountered various barriers. Those, in other words, who sought healthcare 'below the

\footnotetext{
* Corresponding author.

E-mail addresses: hintjens@iss.nl (H.M. Hintjens), siegmann@iss.nl (K.A. Siegmann), staring@law.eur.nl (R.H.J.M. Staring).
} 
radar', rather than as provided for in the law. In contrast with some other studies that focus mainly on healthcare providers and services (see Grit et al., 2012, for an example) our pilot study started with the self-defined healthcare needs and experiences of undocumented people themselves.

This study corroborated wider evidence that undocumented people in The Netherlands are still not accessing, and sometimes decide to avoid, the 'medically necessary' healthcare they are legally entitled to (Biswas et al., 2012: 52). Even though Dutch law provides more health rights to undocumented people than Belgian law, for example, undocumented people in The Netherlands have been reported to be twice as likely as those in Belgium, not to be able to access the medical healthcare they need (Van Ginneken and Gray, 2013: 347).

In light of this, the present study addresses one simple question: Why are so many undocumented people not able to exercise their formal legal rights to 'medically necessary' healthcare, as defined in Dutch law? Is this because they are not informed of their legal rights? Is it "fear of having to pay the bill" that prevents them from seeking healthcare in the first place (Biswas et al., 2012: 53)? Or is there some other reason they fear contact with healthcare institutions and providers and thus avoid seeking medical treatment? What role could attitudes and ignorance of healthcare providers play in the scenario of undocumented migrants being excluded - and excluding themselves from healthcare services? All these angles are considered in this study.

We use the term 'undocumented' broadly, for migrants who have entered irregularly, have failed in their asylum claims, or have overstayed after entering legally (Merlino and Parkin, 2012: 3). Other terms like clandestine, unauthorized or illegal tend to imply guilt on the part of those without documents, so the term undocumented is preferred in this study. Generally, we sought insights from undocumented people, focusing on two Dutch 'global cities' - The Hague and Rotterdam, cities in which we also live and work. Entitled: "Count Us In": Towards Realising Health Rights among Undocumented People in Two Dutch Global Cities", the original pilot project was funded by the Rotterdam Global Health Initiative (RGHI). This article is our first presentation in print of the results of the pilot study (2012-15) and draws on interviews by a team of mostly undocumented researchers trained in the PEER (Participatory Ethnographic and Evaluation Research) methodology. We are extremely indebted to all of them, and would love to mention their names here, but cannot do so, for obvious ethical reasons. Codes used to protect the identity of interviewees are presented in Table 1, below. In quotations from PEER interviews, we use the unique numbers stored in ATLAS.ti for the interviews. Table 1 is an overview of all the interviews conducted, their location, their sex and their national origins. We wish to thank the two anonymous reviewers of this article for their inputs into improving its coherence and pushing us to clarify our arguments.

Before the study, we heard anecdotal evidence that the few hospitals, clinics and GPs considered 'friendly' healthcare providers, ended up with a heavy burden of care. Other GPs, hospitals and clinics seemed to filter out undocumented people through subtle or less subtle forms of discrimination and prejudice. For children, there are also institutional obstacles to access, as with the national vaccination program. Inclusion depends on parents being invited through routine reminders from the municipal health services, that their children's injections are due.

After this overview of the Dutch healthcare system and the problem of undocumented people failing to access healthcare, the next section discusses the 'liminal' status of undocumented people. After that we explain why the PEER approach was selected, and how it has translated into practice with PEER researchers in The Hague and Rotterdam. We then report the key findings from interviews and other studies, including the fear of detection, worries about medical treatment costs and healthcare providers' negative attitudes. The final section before the conclusion reviews some strategies undocumented men and women use 'below the radar', to keep themselves healthy.
Table 1

Interviews conducted in The Hague and Rotterdam.

\begin{tabular}{|c|c|c|c|c|}
\hline Atlas.TI File Number & $\begin{array}{l}\text { Country of } \\
\text { Origin }\end{array}$ & Female (f) & Male (m) & $\begin{array}{l}\text { Location of } \\
\text { Training/ } \\
\text { Interview }\end{array}$ \\
\hline $\mathrm{DOa}^{\mathrm{b}}$ & Congo (DRC) & & 1 & The Hague \\
\hline $\mathrm{D} \mathrm{b}^{\mathrm{b}}$ & Nigeria & 1 & & The Hague \\
\hline $\mathrm{D} 0 \mathrm{c}^{\mathrm{b}}$ & Zambia & 1 & & The Hague \\
\hline D1 $\mathrm{a}^{\mathrm{a}}$ & Algeria & & 1 & The Hague \\
\hline $\mathrm{D} 1 \mathrm{~b}, \mathrm{c}, \mathrm{d}^{\mathrm{a}}$ & Guinea & & 3 & The Hague \\
\hline $\mathrm{D} 1 \mathrm{e}^{\mathrm{a}}$ & Egypt & & 1 & The Hague \\
\hline $\mathrm{D} 1 \mathrm{f}^{\mathrm{a}}$ & Sudan & & 1 & The Hague \\
\hline D2(f), D3(f) D9(m) & Philippines & 2 & 1 & Rotterdam \\
\hline D4 & Nicaragua & 1 & & The Hague \\
\hline D5 & Colombia & 1 & & The Hague \\
\hline D7-D10(f) D11(m) & Philippines & 7 & 1 & The Hague \\
\hline $\begin{array}{l}\text { D12-D16; D18- } \\
\text { D20(f); D17(m), } \\
\text { D21(m) }\end{array}$ & Indonesia & 7 & 2 & The Hague \\
\hline Total interviews & & 20 & 10 & The Hague \\
\hline D22(f), D43 & Surinam & 1 & 1 & Rotterdam \\
\hline D23/D33 & Somalia & 2 & & Rotterdam \\
\hline D24/D41 & Indonesia & & 2 & Rotterdam \\
\hline D25 & Guinea & 1 & & Rotterdam \\
\hline D26/D37/D42 & Myanmar & & $1(3)^{c}$ & Rotterdam \\
\hline D28 & Morocco & 1 & & Rotterdam \\
\hline D29/D34/D38 & $\begin{array}{l}\text { Angola/Cape } \\
\text { Verde }\end{array}$ & & $1(3)^{c}$ & Rotterdam \\
\hline D30 & Uganda & & 1 & Rotterdam \\
\hline D31 & West Africa & & 1 & Rotterdam \\
\hline D27/D39 & Tanzania & $1(2)^{c}$ & & Rotterdam \\
\hline D35 & $\begin{array}{l}\text { Tanzania/ } \\
\text { Burundi }\end{array}$ & & 1 & Rotterdam \\
\hline D36/D40 & Unknown & 1 & 1 & Rotterdam \\
\hline D44 & India & 1 & & Rotterdam \\
\hline $\mathrm{D}^{\mathrm{b}}$ & Bangladesh & & 1 & Rotterdam \\
\hline Total interviews & & 9 & 15 & Rotterdam \\
\hline Overall Total & & 29 & 25 & Both cities \\
\hline
\end{tabular}

a Six interviews recorded under one number in Atlas.TI - indicated by D1a-f.

b Early interviews/test interviews; transcripts not entered into Atlas TI system.

c More than one interview with the same person.

\section{Health rights and realities: theorizing liminality}

Our starting premise is that global health justice principles should apply to undocumented people, whether in The Netherlands or elsewhere. Effective access to healthcare should be possible for every person in society, since only in this way can the fundamental human right to decent health be fulfilled. The right to health for all, without discrimination, is recognized in Article 12 of the International Covenant on Economic, Social and Cultural Rights (ICESCR), and in Article 11 of the (Revised) European Social Charter. Furthermore, Article 24 of the Convention on the Rights of the Child (CRC) further extends to: “... all women and children a right to health, without regard to legal status":

"International human rights law recognizes that a right to health benefits everyone residing in a state's territory. Thus, undocumented migrants have a right to healthcare on a non-discriminatory basis. [...] In the Netherlands, undocumented migrants have access to a wider range of healthcare services; therefore, the Netherlands is, in principle, meeting its international obligations" (Biswas et al., 2012: 55).

Although Dutch law provides the right to 'medically necessary' healthcare for all undocumented people, there is at present no agency responsible for monitoring whether this law is being implemented or not. Health needs of undocumented people are hardly known, reflecting their wider invisibility within Dutch society. Indeed, this non-surveillance of undocumented people's health needs testifies to a certain officially-sanctioned neglect (Hintjens, 2013). It was this perceived 
neglect that motivated us to seek out more qualitative modes of generating data about undocumented people's health needs and experiences. We too had to go 'below the radar' if we were to enable undocumented people to speak frankly of their experiences within the Dutch healthcare system. Given their 'liminality', their uncomfortable relationship with the state, and with the authorities in general, making spaces for undocumened people to talk would not prove easy. As Turner explains, typically:

"The attributes of liminality or of liminal personae ('threshold people') are [...] neither here nor there; they are betwixt and between the positions assigned and arrayed by law, custom, convention, and ceremonial" (Turner, 1969: 95).

Squeezed into 'the margins', the undocumented often feel they have no 'right to have rights' (Arendt in Bhabha, 2009). This makes it less likely they will assert their rights to medical treatment in any organized way. As one male interviewee explained, stigmatisation can result:

"Illegals have no doctor, no insurance, no right to a doctor ... I have never been to a doctor .... I had no documents and I was told; you are an illegal, so you are a criminal ... that is why they put me in prison ... I really do not dare to go to the doctor ... these days I get angry very quickly ... I want to fight with everyone ... I was not like that before" (D1b Interview, The Hague, December 2013).

This insecurity makes it difficult to build trust with undocumented people, or to agree to be interviewed (Staring and Aarts, 2010). Our priority in this pilot study was to enable undocumented people to speak freely and frankly to PEER researchers. To achieve this, we had somehow to overcome the legacy of distrust that resulted from the Dutch government's 'deterrent' approach, including recent efforts to criminalise anyone who is undocumented.

Estimates of how many undocumented people live in The Netherlands are problematic, since by definition, those living 'below the radar' are not routinely surveilled, whether by state authorities or by researchers (see Fazel-Zarandi et al., 2018; Capps et al., 2018; Hintjens, 2013). Borrowed from biology (Chao, 1987; Poorolajal et al., 2017) the so-called 'capture-recapture' method has sometimes been used to study 'sensitive' populations, like HIV-AIDS sufferers, and also undocumented people living in The Netherlands (Bohing, Van der Heijden \& Bunge, 2017). However, this method has not been without its critics (see for example Tilling, 2001).

LOS (Landelijke Ongedocumenteerde Stichting, the National Undocumented Association) put the estimated number of undocumented people in The Netherlands in 2015, at 100,000, which is quite close to other estimates for 2002-2008, of between 62,000 and 131,000 (Kovacheva and Vogel, 2009). The capture-recapture method results in generally lower estimates, for example of 20,654 to 63,015 in 2009 (Van der Heijden et al., 2011), and of 22,881 to 48,179 between June 2012 and June 2013 (Van der Heijden et al., 2015; see also Van der Heijden et al., 2006: 12). For the two cities in this study, Rotterdam and The Hague, available estimates are based on the 'capture recapture method'. For Rotterdam, a city of 616,294 people in 2013 , there were an estimated 7547 undocumented people, $1,2 \%$ of the population. In The Hague, of 505,856 inhabitants in 2013, an estimated 3188 were undocumented, just $0,6 \%$ of the city's population (Van der Heijden et al., 2015: 1).

Whatever the precise numbers of undocumented people, we considered it very unlikely that we would be able to interview a 'representative' sample in the time and within the budget available for the pilot study, and for this reason the PEER method was included in the request for funding. Starting from the perspective of undocumented people, we opted instead for in-depth and sensitive qualitative interviews, with small samples and open-ended questions. Potentially this could yield richer insights than a larger-scale, more structured survey. Even so, PEER researchers often found the interview process highly unpredictable. Even when arranging to interview people they knew, some interviewees failed to keep appointments, or failed to open up once they did meet (see interviews marked + in Table 1 below). The likely reasons for such hesitation included the fear of being identified.

PEER interviewers were trained in building trust, so they could 'dig deeper' into undocumented people's experiences with Dutch healthcare providers; the stories of undocumented people mattered to us. As Tilly reminds us: "Stories do social work. They not only help account for puzzling, unexpected, dramatic, problematic, or exemplary events, but also help confirm, redefine or challenge social relations" (Tilly, 2006: 93). We now explain the PEER method and how the PEER training was carried out.

\section{Adapting the PEER methodology}

A guiding premise of the PEER methodology is "that what people say about social life and behaviour changes according to the level of familiarity and trust established between the researcher and researched" (Price and Hawkins, 2002: 1328; see also Crawley et al., 2011: 12-13). To generate valid, previously unconfirmed data about liminal, 'invisibilised' undocumented people, the PEER methodology we used brought interviewees' concerns into the research agenda from the start. Our aim was to generate stories that would give insights and raise awareness among health professionals, of undocumented people's difficult situation, perhaps even offering some tentative solutions. It was also hoped the PEER approach could reduce power imbalances between researchers and interviewees, thus making frank disclosure more likely (Cunningham and Diversi, 2012; Guemar and Hintjens, 2013). We recognise these were quite ambitious aims.

\subsection{Practicing the PEER approach}

After obtaining funding and ethical approval for the research design from the Rotterdam Global Health Initiative, from June 2013 onwards, teams of male and female volunteer interviewers were recruited, first in The Hague, and then in Rotterdam, and were trained in the PEER methodology. In Rotterdam in particular, we drew on contacts with ROS (Rotterdam Ongedocumenteerde Steunpunt, the Rotterdam Support Centre for the Undocumented). Several of our PEER researchers in The Hague were involved with Migrante and IMWU (Inodnesia Migrants Workers Union), which represent Filipino and Indonesian migrant workers, respectively. Most PEER researchers were undocumented, or had been undocumented in the past. We were unable to pay them, providing only a honorarium that covered travel and hospitality expenses, reimbursing their tickets and receipts. The PEER researchers shared computers for recording, transcribing and translating interviews. Some were labour migrants, others failed asylum seekers. Of four PEER researchers with legal status, two had previously been undocumented. Seven PEER researchers conducted interviews in The Hague between October and December 2013. Somewhat later, eight PEER interviewers were trained in a series of Rotterdam workshops, and of these five went on to conduct interviews between October and November 2014. Training materials for all interviewees were agreed in the first PEER workshop in The Hague in August 2013. As is recommended by others, the PEER researchers also helped with initial analysis of the interview findings (cf. Lushey and Munro, 2014: 527).

PEER training included discussions, role play, problem-solving, and group reflection on suitable questions. Training also included practice around non-directive interviewing techniques. Open-ended questions and prompts were designed, to encourage respondents to talk. A way of handling confidentiality was agreed. PEER researchers, when interviewing the undocumented, were to cover four areas: a) perceived health needs; (b) previous health-seeking behaviour; (c) obstacles experienced in trying to obtain healthcare, and (d) how they would improve healthcare services. In The Hague PEER workshop of August 2013, the PEER team and the academic researchers together produced a 12-page guideline document, which included non-directive questions, 
prompts, and outlined the study and its goals. This guideline document was translated into English, Dutch, French, Spanish, Chinese and Portuguese, with a summary in Bahasa (Indonesian).

When interviews took place, PEER researchers often advised and advocated for undocumented people (see Keygnaert et al., 2012: 507 on this). To assist with rapport-building, interviews could be in the third person, since by referring to a 'friend' or 'neighbour' and their difficulties, interviewees could feel safe from revealing potentially humiliating experiences (Guemar and Hintjens, 2013: 70). Some PEER interviewers knew their interviewees, which made it easier for them later on to help identify key themes in interview transcripts, in follow-up workshops. We would like to believe that the decision to avoid more formal interviews, or a survey of undocumented people, was justified in relation to the results obtained, as reported in this article. Before starting the study, we consulted with municipal health authorities in both Rotterdam and The Hague to hear of their concerns. However, we deliberately prioritized the points of view of undocumented people, including of our PEER researchers, in elaborating our key questions.

\subsection{The respondents}

Some PEER researchers already knew one another, especially those involved in campaigning around undocumented people's rights. In the workshop they interviewed one another, in preparation for the 'real thing'. Through 'snowball' sampling, other interviewees were identified, and this informal, networked approach helped most respondents open up and discuss their hopes, fears and experiences with the interviewers in quite a frank way. With more interview experience, some PEER interviewers became highly skilled in asking even the most sensitive questions around access to healthcare. Occasionally, an initial interview was followed up by a second (and in one case, a third) longer interview (see Table 1 below for details). Overall, PEER researchers in The Hague conducted interviews between October and December 2013, and in Rotterdam between October and November 2014. Of around 50 people interviewed, all but one, who was recently regularized, were undocumented. Interviews lasted from 15 to $45 \mathrm{~min}$, and in all but three cases, were recorded, transcribed and analysed in QDA software ATLAS.ti. Table 1 shows the nationality and sex of interviewees, and provides ATLAS.ti codes for almost all interviewees cited. Not all interviews listed in Table 1 are referred to in this article.

Interviewees ranged from those in their twenties, to people over sixty. They included migrant workers and failed asylum seekers. Some worked and sent money home, others relied on charities, NGOs, churches or friends, in order to survive.

\section{Seeking health below the radar: PEER interview data}

Living life 'below the radar', undocumented people generally navigate access to healthcare in a cautious manner. As the Health for Undocumented Migrants and Asylum Seekers (HUMA) Network notes in one of their reports, in The Netherlands:

"Undocumented migrants can only access care considered by doctors on a case by case basis as 'medically necessary'. The rule is that they will have to pay for it unless it is proven they cannot pay. If this is the case, healthcare providers, hospitals and pharmacies will provide care or treatment and then ask for reimbursement to the specific public fund" (2009: 15).

An often business-like attitude of Dutch health providers can result in informal obstacles, often at the reception, when patients are asked for insurance documents, or asked to identify themselves with ID. If they cannot do so, they will be billed, and they need to reply stating they cannot pay. The next sub-section reviews some perceived health needs of undocumented informants, considering fear, distrust and stigma as barriers to access. The follow sub-sections discuss fear and distrust as obstacles, the economic costs of healthcare, and attitudes of healthcare providers towards undocumented people's right to medically necessary healthcare.

\subsection{Health problems under the radar}

A majority of undocumented people describe their health status as poor, and yet tend not to visit medical practitioners. The reasons they give include not having health insurance, fearing identification, being unable to pay, and a lack of awareness of their healthcare entitlements in law. One Rotterdam interviewee, also a PEER researcher, from Tanzania, said:

"People who have a paper, they have verzekering [health insurance], so when they get sick, they know where to go. But if you don't have a paper, then you don't know where to go. So you just hope that the sickness goes away. If you're worse, you have no choice; you have to go to hospital ..." (D39 Interview, Rotterdam, November 2014).

Psychological and psycho-somatic problems are particularly common among those whose asylum claims have failed, and these problems are rarely treated (Kulu Glasgow et al., 2000). According to one major review study, conducted in 2009 , and “... drawing on 181 surveys with 81,900 refugees and other conflict-affected people" (Silove et al., 2017: 131), the prevalence of PTSD and depression among the undocumented was around 30 per cent. Exposure to torture and the total number of trauma events experienced emerged as the strongest predictors of PTSD and depression, respectively. A study by PICUM (2007: 65) points to another problem that may be more institutionalized, namely the lack of awareness about relevant legal frameworks and policies among healthcare providers and health administrators, rather than among migrants.

The longer the duration of their stay in the Netherlands, the more psychological problems the undocumented tend to experience. D1a has been in the Netherlands for decades, since the mid-1990s, and is now very sick indeed, with high blood pressure, heart problems and severe psychiatric problems, including psychotic episodes. He constantly thinks of self-harm and suicide. Unusually, he claims he has no difficulty at all accessing the doctor or seeking medical help. Many organisations seem willing to help him, including the municipal mental health service, the GGZ (Geestelijke Gezondheids Zorg). Talking to a PEER interviewer in The Hague, he explains: "For my own safety, I have my medicines with me every day, so that everyone can see what is wrong with me. And I can simply go to the doctor. I can just go right there" (D1a Interview, The Hague, December 2013). This is the same man quoted at the start of this article, who said his medicines are his 'wife'. At risk of self-harm, he may be given free access to medical care for public health reasons.

Like this man, many other long-term failed asylum seekers are single men, living alone without family. Those with children worry about their children's future even more than their own (Van den Muijsenbergh and Schoevers, 2009: 61). As one male undocumented worker explained: “... for us who do not have permission to live here and ... have children here, it is also a problem for us if our children are sick" (D12 Interview, The Hague, December 2013). Under the law, children are more protected than adults, but still may not receive proper healthcare, since if their parents fear taking their (fully entitled) children to the GP, they will self-exclude their children too. Where landlords and employers are concerned, there are other fears. As one interviewee said, talking of his landlord:

"The people who we live at their home [i.e. the landlord] are afraid because they keep undocumented people. They are afraid to get any fine or anything. They are afraid [to go to the hospital or GP with us because] of dealing with the police" (D17 Interview, The Hague, October 2013).

The obstacles undocumented people encounter in their search for healthcare, take many different forms. Interviewees often also stated 
'we are human', asserting that even those with 'illegal' status, have the right to access medical care. The following extensive quote from one undocumented woman from Tanzania, illustrates this point:

"They come to me and they ask me and they are really crying and sometimes you go sit there. They fear to go to hospital because they don't have a passport or they don't have papers and they will be crying. Or maybe they even have an accident and they don't know; they cannot go to hospital to heal their wounds and everything ... Because of fear the police will catch them or the doctor will give them bad medicine and everything. But I've been able to talk to some of them, not to get scared, because they are human, if they are sick, go and get treated. But the thing is they don't know where to be treated, that is it" (D27 Interview, Rotterdam, October 2014).

She addresses several issues, including widespread fear of the police, general distrust of medical ethics, and of being unequally treated or even 'experimented' on with 'old' or 'bad' medicines. She stresses a lack of knowledge about fundamental health rights, and where to be treated for what. Although fear and knowledge deficiencies can reinforce social exclusion, the idea of 'being human' as expressed here, underscores the hope of common and equal rights of all to healthcare. We now consider some obstacles, from the perspective of undocumented people interviewed for this pilot study.

\subsection{Obstacles: fear, distrust, stigma}

Perhaps our single most notable finding was that fear of the authorities, sometimes compounded by a lack of knowledge about rights or lack of support networks, can account for many undocumented people avoiding doctors, hospitals and other healthcare providers. Talking in the third person, one man from Congo DRC reports:

“... there is a woman I know. She is sick but she will not go to the doctor. She does not know what may happen to her if once they ask for her papers .... She thinks maybe ... the doctor works for IND and she was very afraid. She leads a life of stress, she has headaches, insomnia ... she does not know how to go out or to see the doctor and his [her] situation becomes more serious" (D0a Interview, The Hague, October 2013).

It is interesting that not knowing 'what may happen' includes the worry that the doctor 'works for IND' (the Immigration and Nationality Department of the Dutch government). Several other respondents also stated they did not trust the health authorities not to inform the police, or call them to come and arrest them as undocumented. Even when in pain, self-exclusion and self-medication were commonplace. Even those who knew their own rights to healthcare under the law, hesitated to report illness or accidents at work, for fear of their employers being prosecuted. In line with other research (Biswas et al., 2012: 56) we found undocumented people especially lacked access to dental care both acute and routine - in both Rotterdam and The Hague.

More seriously, fearing arrest, detention and deportation, some undocumented people suspect that medical staff share their details with the police. The police are generally feared, and thisi is yet another reason for 'keeping to oneself'. One female interviewee in The Hague explained how this circumscribed her life and that of her undocumented friends:

(Text here should be indented (quote "we are more ... careful to keep ourselves .... not be involved in criminal activity or make the slightest mistake like one does not pay attention to cross the light, not paying the ticket, or for example like looking for a fuss with friends or with people here. We must also be disciplined [even in] ... taking out the trash, follow the rules of life for people here in more detail. Even the people here [the Dutch] are not as detailed as we are. We are more cautious just to avoid any problems" (D13 Interview, The Hague, November 2013).(end of indented text).

The 1998 Koppelingswet (Linking Act) made access to all basic services such as housing, education (over 18) and even the duty to pay health insurance, dependent on having valid identity documents (Engbersen and Van der Leun, 2001: 66). Data-sharing across government departments became the norm, and undocumented people seem particularly aware of this. One Rotterdam interviewee stated "the [undocumented] people rarely complain ... thinking [if] they go to the doctor, [the] doctor maybe call the police or something" (D37 Interview, Rotterdam, November 2014).

Fears of detection through medical institutions may not be realistic, since there is no direct evidence from any other source that medical staff report undocumented people who seek medical treatment, to the police. Yet as Van der Leun and Ilies (2008: 12) and others (Engbersen et al., 2007) have noted, sharing information is integral to the 'Linking Law' and although cross-departmental data sharing should respect patient confidentiality, the Netherlands government's explicit 'discouragement policy' towards illegal residence, means that, in effect:

“... the Dutch state tries to exclude irregular immigrants from public services (welfare, social security, healthcare, education, and public housing). In 1998, the Benefit Entitlement (Residence Status) Act came into force ... This act is also known as the "Linking Act" because immigration service registration files, census bureau data, fiscal identification agency data, and social security and social assistance data can all be cross-checked to verify the validity of immigrants' residence and work status" (Engbersen et al., 2007: 424).

Under this act, those without legal residency lost the right to purchase health insurance, even if they could afford to do so (Ingleby et al., 2016: 21). Several undocumented interviewees stated that they would be glad to pay for insurance, if this were allowed.

Relations with healthcare institutions and staff were experienced by some interviewees as discriminatory and stigmatizing. Beliefs about second-class treatment are based on experiences of being disregarded or treated badly, and at least two undocumented people interviewed shared a marked sense of vulnerability around their relations with medical staff. Both felt that manipulative behaviour included racism and even possible experimentation on undocumented people's bodies. This quotation from an interviewee in Rotterdam suggests doctors knowingly provide undocumented patients with inferior medical treatment:

"Because the doctors, if they know [that you are an] illegal people, they sometimes do not help so good. [...] Even, I heard something that some people said, illegal people go to hospital, the doctor [passes on] the person to a student. A student takes the operation, so it is really, really painful. [...] They get a treatment, but not so good." (D26 Interview, Rotterdam, November 2014).

Another Rotterdam interviewee thought doctors might administer experimental medications and risky treatments to undocumented people, reserving tried and tested medications for native Dutch (D34 Interview, Rotterdam, November 2014). In general, many fears like these were expressed, reflecting doubts about the authorities, and about the integrity and confidentiality of the medical establishment. Reading these interviews, at times produced the feeling of living: "in a kind of no-man's land between the real and the imaginary, and between innocence and irresponsibility" (Jackson, 2005: 346).

The fear and stress of being undocumented, combined with the very sober, even stoical, attitude of many Dutch medical practitioners, can result in the perception that medical staff and other healthcare providers, simply do not care. One undocumented woman interviewed in The Hague gave an example of dangerous self-medication. She had nightly stomach pains but "just kept ignoring" the pain and, as part of her "night routine" rubbed "on oil before she goes to bed, she keeps doing that every night" (D4 Interview, The Hague, October 2013). This could quite predictably result in an emergency situation that could be lifethreatening, because of a lack of medically necessary care in good time. 


\subsection{Obstacle: lack of economic means}

Their inability to pay for basic living costs, such as food and transport, means very few undocumented people are able to pay for transport to the hospital or GP, let alone for medicines or medical care. Poverty and unemployment, but also low-paid employment, both prevent undocumented people seeking medical treatment in good time. It might seem common sense that working helps undocumented people, yet the work they find generally also exposes them to risks at work, and ill-health complications. Working long hours, without social protection, in dangerous conditions, undocumented workers tend to neglect their own health. Several interviews with undocumented men and women in The Hague and Rotterdam suggested that although work was desired since it brought in money, work could also pose the greatest risk to health and safety for undocumented workers. Many domestic workers, for example, dealt with chronic pain. As one Filipina interviewee observed:

"[...] the most [common] problem of undocumented here is, since our job is cleaning, we have always this back problems or shoulder problems or ... how do you call this now ... hands we cannot fold in the morning" (D09).

Benseddik and Bijl (2004: 139, 147-149) found chronic back, neck and shoulder pain were common among undocumented greenhouse workers. Undocumented workers were compelled to work not only in order to live, but also to support family members at home through sending remittances. Even in the case of serious injuries at work - as when one undocumented worker in a glasshouse lost two fingers (Benseddik and Bijl, 2004: 139) - they may not go for medical treatment, such is the fear that they or their employer might be arrested. Far from protecting undocumented workers, labour inspections tend to drive them and their employers further underground. When Benseddik and Bijl spoke with labour inspectors, later, asking them about the man who lost two fingers, labour inspectors confirmed that they would have had to report him (and his employer) to the immigration and naturalisation service (IND) and call the police. Although labour inspectors are obliged to share information, medical practitioners are generally not expected, and indeed are not supposed, to share patient information in this way.

One Hague interviewee, from Indonesia, works in a factory with other undocumented people. They sleep in their workplace, and he narrates how a leaking gas heater resulted in vomiting, followed by himself and other workers losing consciousness. Fearing police, they did not call for help but simply demanded that the employer replace the gas heater with a new one. He added:

"Just like we told our boss, we said to him that we would not work if it was not replaced. Because the boss does not want to know since we are the ones who work. He said if ... something happens here, it would be our own risk and if we are dead, it is our destiny from God. The boss is from here. I do not know with Dutch people, but the people at my work do not really care about that, the important [thing] is that you work and you are paid. Well, [the] risks [are] for undocumented" (D17 Interview, The Hague, December 2013).

Even in such unsafe and harmful working conditions, undocumented people are often unwilling to go to see the doctor, let alone to report work-related health problems to labour inspection services. Moreover, verbal work contracts are the norm for those without status, and this means that such contracts:

“... can always be cancelled, for example, if illegal workers or tenants are not submissive enough or violate certain rules of conduct. Labour and housing conflicts are then settled by firing or evicting the illegal immigrants or by simply refusing to pay them for the work they have done" (Engbersen and Van der Leun, 2001: 63).

In these ways, lack of protection under the law for undocumented workers and their insecure work situation in relation to their employers, are mutually reinforced. This further deters undocumented people who are working, from seeking medical attention, for example if they are injured in an accident at work or become sick through a hazardous working environment.

\subsection{Obstacle: unwilling medical healthcare providers}

Van den Muijsenbergh and Schoevers (2009: 62) suggest that undocumented people's failure to access healthcare in the Netherlands is mainly due to a lack of knowledge and self-excluding behaviour on the part of the undocumented. In contrast with this, our findings suggest that lack of information on the part of undocumented people may not be the main problem. In addition to the fear of detection and high costs, a perceived lack of care and compassion on the part of medical and healthcare service providers seems to be a significant factor. A recent study of medical staff attitudes towards migrants in 16 European countries, found that:

"The majority of respondents (74\%) asserted that, in general, treatment for migrants after the initial contact would not differ from that for non-migrant patients ... However, for refugees and undocumented migrants only one or two participants respectively reported no difference in further treatment pathways" (Priebe et al., 2011: 4).

Several interviewees mentioned healthcare providers' tendency to prescribe 'paracetamol' as a cure-all, something we return to later. One Rotterdam interviewee summed up the complaints of mistreatment this way: "[we are] human beings, we need ... things, but [these] ... people they don't care about that. They only care about their animals" (D35 Interview, Rotterdam, October 2014). Claims of experimentation and discrimination may not always be factually accurate, but they do powerfully express the intense distrust felt towards (most) healthcare providers, who tend to be viewed as representing the Dutch authorities. Frictions may start at the reception desk, with language barriers and cultural miscommunication, as well as racist attitudes and poor communication skills among staff.

In The Netherlands, any person who arrives at the GP clinic or hospital, is asked for their ID. Our interviews confirmed that some medical and administrative staff in Dutch public hospitals, for example, assume that without ID, undocumented people have no right to healthcare. They seem unaware that undocumented people are not allowed to pay for medical insurance, or to have an ID card. Experiments in Rotterdam to provide an informal 'health passport' for undocumented city residents, were pioneered by ROS for this reason, and seemed to facilitate access to health care for those without other proof of identity.

Interviews also revealed evidence of less-than-professional record keeping among GPs. For example, one woman had been sick and been to the doctor in The Hague for a prescription. As she reports, the doctor told her that if she was still sick two weeks later, she should come back. As she explains (the interviewer's questions are included here for clarity):

D21: "When we came back, we were asked again, our name, what is the complaint. She [i.e. the doctor] forgot! So they have no data about the patients"

Interviewer: "Is it because you're undocumented?"

D21: "Well I do not know, the doctor just said that she had no data in her computer. If I go to the hospital, when I come there, they have all my records. Everything is recorded."

Interviewer: "The patient and the treatment should be recorded. You must pay in cash, right, well, it means the money you have paid is not recorded. It goes directly to her own pocket. Though this helps the undocumented and it does not mean the doctor does black work. 
But if she does not record your data, or your payment, then she is working 'in the black"'.

D21: So she's like me - doing black work!" (D21 Interview, The Hague, December 2013).

In this case it is the interviewer, an experienced migrant rights advocate, legally settled in The Netherlands, suggests the doctor might be working 'in the black', conveying her negative perceptions of the trustworthiness of Dutch doctors. Incidentally, this extract shows how many PEER interviews sound more like normal conversations, than a regular question and answer interview. However, suggesting that GPs might work in the black, challenges the idea that Dutch medical practitioners could not commit illegal activities; it also shows how sometimes PEER interviewers embraced, and then went beyond, the insights of their interviewees. The attitudes of medical and hospital staff could vary from neglect and indifference, to active hostility towards undocumented people. However, as we saw for a few, not necessarily lucky, undocumented people access to medical professionals and drugs were relatively easy, especially where public health issues, such as serious mental health problems, were involved.

\section{Moving beyond the obstacles: building bridges}

Several strategies were distinguished on the part of undocumented people, when it came to their own efforts to live a healthy life, free of disease. For some, eating healthy food and maintaining a basic level of physical fitness, were vital. For others, being accompanied helped reduce their fears. For yet others, 'paracetamol' became a way of coping with illness by self-medicating.

An Indonesian man, claiming his "body has no resistance for the cold weather, because I used to stay in the tropical weather" (D41 Interview, Rotterdam, November 2014), explained how he maintained his own health:

"Every day, I wake up in the morning, I ... do sit-ups and push-ups. Sit-ups are very important for people. Because, in this area [point at the belly], we have the power [...] In our belly we have this power to resist the cold. And I don't smoke, I don't drink, I don't use marijuana, don't do drugs. Only sometimes, some people have fiesta, I drink beer or something or wine. And number two is, we ... eat cheese every day" (D41 Interview, Rotterdam, November 2014).

Whether eating cheese everyday is a recipe for a long and healthy life is less significant here than the way that he expresses his conscious choices about his lifestyle, and how he seeks to access his 'inner power', in an uncertain situation that produces apprehension and stress. In addition to physical exercise, another male interviewee was asked how he kept himself healthy without medication:

"Food ... I don't eat too much. I drink water every day, one litre every day, before I leave [the] house and when I come, every day, one litre, minimally. And ... like I told you, I don't eat too much. And if you eat fish, not too much other kind of food ... then you will be good" (D34 Interview, Rotterdam, November 2014).

One Filipina woman, interviewed in The Hague, explains that to overcome the hostile attitude of medical staff, she sought help from a Dutch woman, who phoned the hospital administration before her visit to explain to them that she could not pay. The woman, who was Filipina, was able to go to hospital without worrying. When she fell sick a second time, the Dutch woman again phoned up the hospital administration. But this time, hospital staff were less friendly, and according to the interviewee:

“... the second time ... when M. called, they just closed their mouth. They just keep quiet, saying ok I received this letter, I got a call it's ok. But I know that not all of them were happy with that situation because you could see their faces ... the way they approach you, the way they talked to you" (D8 Interview, The Hague, October 2013).

Coping through self-medication and self-treatment was often mentioned in the interviews, the medicine most often referred to being 'paracetamol'. This word is repeated almost as a mantra in interviews, sometimes a consolation, sometimes as a criticism of medical practitioners over-prescribing paracetamol. The drug provides pain relief and is very cheap, and is therefore used by undocumented people for all kinds of ailments. Asked what kind of medicine she would use if she were sick, one undocumented interviewee replied "my medicine is, just medicine ... paracetamol, yes paracetamol [ ...] You can buy it in the supermarket, in Lidl, or Ibuprofen" (D27 Interview, Rotterdam, October 2014). One Indonesian interviewee reflected on his friend who needed a dentist:

"One day, my friend had tooth pain, she's is feeling so [much] pain in her ... She can't sleep the whole night and she doesn't know where to go. So she looks for a dentist here and a dentist there. They tell her they cannot treat her because she has no papers, so she has just been taking paracetamol and not working and hoping [but] that can't help her to get the pain away. So I know so many people who get sick and don't have anywhere to go to hospital. That's very sad" (D24 Interview, Rotterdam)

Paracetamol is a by-word for second-class healthcare, seen as a cynical way for doctors to provide low quality, cheap medical care for the undocumented as well as a genuine source of relief and a way to self-medicate. Even medical care inside detention was said to be based on Paracetamol:

D37: "Well, if the police come there, it's not all right. Police putting you in jail, so is not a good place."

Interviewer (I): "Yeah, but if they put you in jail, will they give you some medicine over there in jail?"

D37: “Oh, yeah. They give you paracetamol!”

Interviewer: "Only paracetamol? But surely it depends which kind of sickness you have?"

D37: They don't give any medicines, only paracetamol"

Interview, Rotterdam, November 2014).

Being undocumented can be bad for one's social networks, as people move further below the radar, seeking anonymity and invisibility. One interviewee lost her residency rights a few years after moving to The Netherlands, and had become very cautious:

D7: "If you are undocumented you have to be aware of everything ... for example, we have to choose the people, we have to choose our friends".

Interviewer: "Can you explain what you mean, being aware of what? Your surroundings, the people you are dealing with? Is that what you mean?"

D7: "Yes, sometimes, we don't know ... who we are talking about, or who we are dealing with. So you have to be aware what kind of people these are; are they your friends, your true friends?" (D7 Interview, The Hague, October 2013).

She no longer mixed much within her own community, and felt safer with fewer friends rather than more. D1e, an Egyptian man, expressed a similar sense of social isolation: "in general undocumented people don't go that often to the doctor. We don't have many friends, and our social life is very restricted" (D1e Interview, The Hague, December 2013). Friends are important, of course. One failed asylum seeker described how her friends helped her consult a medical doctor after she got dizzy spells.

NGOs and trade unions generally try to help their members with information. This does not tend to reduce the fear of accessing 
healthcare among most undocumented people, however. What made a difference were friends with legal status, who were willing, for example, to accompany the undocumented person to the GP or to hospital in person, or to phone on their behalf. This kind of individual support made undocumented people feel more confident, and they felt safer in seeking healthcare (D10 Interview, The Hague, December 2013).

NGOs and other professional organisations can provide information, and some material or financial support, for example to cover transport costs. Yet such generic support can hardly be tailored to provide the personal support and accompaniment, tailored to each individual. As one failed asylum seeker from Guinea hinted 'one size does not fit all', and generic advice might fail to deliver the hoped-for results: "sometimes you cannot wait till a specific date when others have time for you. Sometimes it is already too late for medical attention" (D1c Interview, The Hague, December 2013).

Organising information evenings is often seen as a way to support undocumented people, but those who most fear going to medical facilities, GPs or hospitals, are also least likely to attend such events. In one Filipina woman interviewee's opinion:

“... some undocumented even though the government is giving them a chance like for example there is an orientation or there is an awareness ... most of the undocumented they prefer not to show, not to go because they are thinking, oh this is a ... maybe this a way of catching us or tracing us so every negative thinking on the ... that's what they think, that's why they don't bother to show or they don't bother to go to this kind of program" (D7 Interview, The Hague, October 2013).

Sometimes, GPs refers an undocumented person to a specialist, and the individual referred then fails to show up at the hospital and misses their appointment, which irritates GPs and hospitals (Lampion, 2018). Previous experience of such unreliability may then later be used by doctors to deny other undocumented patients follow-up on their healthcare treatment, or to justify a decision not to provide longer-term treatment plans for some undocumented people (Lampion, 2018). Kulu Glasgow et al. (2000) confirm what our PEER researchers recorded several times in interviews, namely that if undocumented people often postpone visits to GPs and other healthcare providers, this is mainly due to their fear of the authorities.

\section{Some forward-looking conclusions}

From the perspective of marginalized groups in society, formal rights mean little unless they can be accessed and realized. Among EU member states, whilst some "provide universal health coverage for nationals, few offer migrants equal coverage. In Germany or Sweden, for instance, migrants in the country illegally can only access emergency services" (Wudan, 2016). Globally, the EU lags behind some much poorer countries in terms of provision. Indeed, Thailand is the one country worldwide, where undocumented people access health insurance and treatment on exactly the same terms as full citizens, refugees and other legal residents (Wudan, 2016).

Broadening access to health is part of wider social justice goals, and central to an actor-oriented perspective that asserts 'the right to have rights' of socially excluded and marginalized people (Pettit and Wheeler, 2005: 3). This study's findings suggest that the liminal position of undocumented people in The Hague and Rotterdam, is not mainly a question of legal rights, but of anxieties among undocumented people, and some health providers' attitudes towards them. Fear-induced avoidance behaviour worsens the health status of undocumented people, but reduces what they perceive as the risk of being detected. Staying hidden 'below the radar' implies that undocumented people seek to avoid formal healthcare institutions and providers, except in an emergency.

Unfortunately, they are right to be anxious. Towards the end of our own pilot study, it emerged that a covert police surveillance operation had been on-going to 'catch' undocumented people regularly travelling to work via The Hague Central Station. Friends of two of our PEER researchers were arrested in dawn raids on their homes, detained and deported. This proved very traumatic for our PEER researchers, with whom we had met in the Central Station as a convenient meeting place, on several previous occasions, and who passed through Central Station, often several times a day themselves.

This study's findings, based on a fairly small sample, are not generalizable, but we hope they provide some deeper insights for policymakers and other researchers about how even a healthcare system where legal rights are quite strong, might be improved and made more accessible for undocumented people. Building relations of trust is vital before improved access can be achieved, and would be in the interests both of undocumented people and the government's public health agendas. Perhaps ties between government health policy makers and NGOs, could:

“... foster supportive peer relationships that endure... Preliminary research suggests [this] ... has the dual effect of increasing civic participation (and hence social capital) and improving participants' mental health" (Silove et al., 2017: 136).

Presumably this could also improve their physical health. In addition, the merits of the healthcare (re)funding scheme in place since 2009, and updated in 2018, need to be better understood by Dutch healthcare professionals and staff in general. Today, just as a decade ago: "Individual caregivers as well as institutions still are not aware of the regulation, and therefore undocumented migrants run the risk of being refused by these aforementioned caregivers" (HUMA Network, 2009: 118). Recently, the Johannes Wier Foundation, an Amsterdambased NGO dedicated to health and human rights, designed an on-line accredited training course for health professionals on undocumented people's health rights (JWS, 2018). This resource could enable Dutch healthcare professionals to contribute more positively towards ensuring undocumented people feel safe to access healthcare more regularly in future, and not only in an emergency.

Unfortunately, fear may be the intended, rather than an accidental, outcome of refugee and migration policies in The Netherlands (as across the EU). The impact of the fostering of a 'hostile environment' on the well-being (and especially mental health) of asylum seekers, is predictably destructive. There are:

"Growing number of studies in recipient countries [which] found that imposed conditions of adversity, including prolonged detention, insecure residency status, challenging refugee determination procedures, restricted access to services, and lack of opportunities to work or study, combined in a way that compounded the effects of past traumas in exacerbating symptoms of PTSD and depression" (Silove et al., 2017: 132).

In the opening quotation: "My medicines are my wife", an undocumented man suggests his medicines have made his life bearable. As with a wife, he depends on these drugs emotionally and physically, for his well-being and mental stability. Since 2016, undocumented people have been able to report crimes to any police station in The Netherlands, without risking arrest. Perhaps the Dutch government could consider extending this right to report to other areas, such as labour rights and accidents at work. This could improve working undocumented people's prospects of accessing healthcare services.

Ultimately, with new data protection laws in place, undocumented people need reassurance that their identity will be protected through confidential handling of their data by the healthcare system. Only if the fear of being reported to the police or immigration authorities, is dispelled, will undocumented people end their self-exclusion from healthcare, so that they can finally secure their rights to medical treatment, as already provided for under the law and through the health costs compensation scheme of the Dutch government. 


\section{Credit author statement}

Helen Hintjens, Karin Siegmann and Richard Staring together conceived of the idea of this proposal. Hintjens was the main applicant, and Siegmann and Staring were involved at every stage, along with Hintjens, of implementing training in the PEER methodology in the cities of The Hague (mainly Siegmann and Hintjens) and Rotterdam (mainly Staring and Hintjens). All were involved in working with PEER researchers in the two cities, in organising workshops to report back and synthesise findings, where Siegmann took the lead, and in presenting the findings, jointly or individually, at a number of scholarly and professional conferences. The findings and analysis of the research have not been published until now.

\section{Declaration of competing interest}

None.

\section{Acknowledgements}

We would like to thank the Rotterdam Global Health Initiative, and particularly its former Director, Godelieve van Heteren, and the Board of RGHI, for their generous and flexible support - both financial and moral - for this pilot project. In spite of the difficulties of conducting this kind of qualitative research with a hard-to-reach population, undocumented people, RGHI funding made it possible to initiate this pilot study in two Dutch cities. We would like to express our gratitude for their faith in us, and hope this first discussion of the findings provides them with an overview of how important their support was at the early stages of a longer-term research process. We would also like to thank Joanne Hemmings of Options UK for her invaluable support in the PEER training in The Hague.

\section{Appendix A. Supplementary data}

Supplementary data to this article can be found online at https:// doi.org/10.1016/j.socscimed.2020.112822.

\section{References}

Bhabha, J., 2009. Arendt's children: do today's migrant children have a right to have rights? Hum. Right Q. 31 (2), 410-451.

Benseddik, A., Bijl, M., 2004. Onzichtbaar achter glas. In: Onderzoek naar de bijdrage van illegalen in de glastuinbouw van het Westland. Stek, Okia, Den Haag.

Biswas, D., Toebes, B., Hjern, A., Ascher, H., Norredam, M., 2012. Access to healthcare for undocumented migrants from a human rights perspective: a comparative study of Denmark, Sweden, and The Netherlands" Health Hum. Rights 14 (2), 49-60.

Bohning, D., van der Heijden, P.G.M., Bunge, J., 2017. Capture-recapture Methods for the Social and Medical Sciences. Chapman and Hall/CRC.

CAK, 2019. Regeling Onverzekerbare Vreemdelingen (Regulations for Uninsurable Foreigners). https://www.hetcak.nl/zakelijk/regelingen/onverzekerbarevreemdelingen, Accessed date: 1 March 2019.

Capps, R., Gelatt, J., Van Hook, J., Fix, M., 2018. Commentary on "The number of undocumented immigrants in the United States: estimates based on demographic modeling with data from 1990-2016. PloS One 13 (9), e0204199. https://doi.org/10. 1371/journal.pone.0204199.

Chao, A., 1987. "Estimating the population size for capture-recapture data with unequal catchability" Biometrics 43, 783-791.

Crawley, H., Hemmings, J., Price, N., 2011. Coping with Destitution: Survival and Livelihood Strategies of Refused Asylum Seekers Living in the UK, Report for Oxfam Cymru, Centre for Migration Policy Research (CMPR). Swansea University, Swansea.

Cunningham, M.J., Diversi, M., 2012. "Aging out: youths' perspectives on foster care and the transition to independence" Qual. Soc. Work 12 (5), 587-602.

De Nationale Ombudsman, 2013. Medische zorg vreemdelingen: Over toegang en continuïteit van medische zorg voor asielzoekers en uitgeprocedeerde asielzoekers. Medical Care of Foreigners: Concerning Access and Continuity of Medical Care for Asylum Seekers and Failed Asylum Seekers), Report Number 2013/125, The Hague.

Engbersen, G., van der Leun, J., 2001. "The social construction of illegality and criminality" Eur. J. Crim. Pol. Res. 9 (1), 51-70.

Engbersen, G., van der Leun, J., De Boom, J., 2007. The fragmentation of migration and crime in The Netherlands. Crime Justice 35 (1), 389-452.

Fazel-Zarandi, M.M., Feinstein, J.S., Kaplan, E.H., 2018. "The number of undocumented immigrants in the United States: estimates based on demographic modeling with data from 1990 to 2016" PloS One 13 (9), e0201193. https://doi.org/10.1371/journal. pone.0201193.

Grit, K., Den Otter, J., Spreij, A., 2012. Access to healthcare for undocumented migrants: a comparative policy analysis of England and The Netherlands. J. Health Polit. Pol. Law 37 (1), 37-67.

Guemar, L.N., Hintjens, H., 2013. The peer ethnographic approach: a suitable method for researching the lives of undocumented migrants? Tijdschrift Cult. Criminaliteit 3 (1), 69-81.

Hintjens, H., 2013. Screening in or out? Selective non-surveillance of unwanted humanity in EU cities. Surveill. Soc. 11 (1/2), 87-105.

HUMA Network, 2009. Health for Undocumented Migrants and Asylum Seekers Network. Human Access to Healthcare for Undocumented Migrants and Asylum Seekers in 10 EU Countries. Law and Practice.. http://www.episouth.org/doc/r documents/ Rapport_huma-network.pdf, Accessed date: 1 March 2019.

Ingleby, D., Devillé, W., Van Dijk, R., Van den Muisenbergh, M., Seeleman, C., Essink-Bot, M., 2016. Migrant Integration Policy Index Health Strand. Country Report Netherlands. IOM, Brussels. https://eea.iom.int/sites/default/files/publication/ document/NETHERLANDS_MIPEX_Health.pdf, Accessed date: 1 March 2019.

Jackson, J.E., 2005. Stigma, liminality and chronic pain: mind-body borderlands. Am. Ethnol. 32 (3), 332-353.

JWS, 2018. Johannes Wier Foundation. E-learning cursus Gezondheidszorg voor ongedocumenteerden (E-learning course on Healthcare for the Undocumented. https:// www.johannes-wier.nl/documentatie/e-cursus-gezondheidszorg-voorongedocumenteerden/, Accessed date: 1 March 2019.

Keygnaert, I., Vettenburg, N., Temmerman, M., 2012. Hidden violence is silent rape: sexual and gender-based violence in refugees, asylum seekers and undocumented migrants in Belgium and The Netherlands. Cult. Health Sex.: Int. J. Res. Intervention Care 14 (5), 505-520.

Kovacheva, V., Vogel, D., 2009. The Size of the Irregular Foreign Resident Population in the European Union in 2002, 2005 and 2008: Aggregated Estimates. Hamburg Institute of International Economics. Database on Irregular Migration. Working Paper No.4/2009.

Kulu Glasgow, I., Bakker, D., Weide, M., Arts, S., 2000. Illegalen aan de 'Poort' van de Gezondheidszorg: Toegankelijkheid en Knelpunten in de Zorg van Huisartsen, Verloskundigen en Spoedeisende Hulpafdelingen (Illegals at the 'Gate' of Healthcare: Access and Obstacles in GP, Specialist and Emergency Care Delivery). NIVEL, Utrecht.

Lampion, 2018. Jaarverslag Lampion 2017 (2017 Annual Report). available at: http:// www.lampion.info/documents/doc/lampion\%20jaarverslag\%202017.pdf, Accessed date: 1 March 2019.

Lushey, C., Munro, E.R., 2014. Peer research methodology: an effective method for obtaining young people's perspectives on transitions from care to adulthood? Qual. Soc. Work 14 (4), 522-537.

Merlino, M., Parkin, J., 2012. Irregular Migration in Europe: EU Policies and the Fundamental Rights Gap. Centre for European Policy Studies (CEPS), Brussels.

Pettit, J., Wheeler, J., 2005. "Developing rights? Relating discourse to content and practice" IDS Bull. 36 (1), 1-8.

Pharos, 2013. Vreemdelingendetentie en gezondheidzorg: Kennisdocument (Foreigners' detention and healthcare: knowledge document) October, author Erik Vloeberghs, Utrecht: Pharos.

PICUM, 2007. Platform for International Cooperation on Undocumented Migrants Access to Healthcare for Undocumented Migrants in Europe, Brussels.

Poorolajal, J., Mohammadi, Y., Farzinara, F., 2017. Using the capture-recapture method to estimate the human immunodeficiency virus-positive population. Epidemiological Health 39. https://doi.org/10.4178/epih.e2017042.

Price, N., Hawkins, K., 2002. "Researching sexual and reproductive behaviour: a peer ethnographic approach" Soc. Sci. Med. 55 (8), 1325-1336.

Priebe, S., Sandhu, S., Dias, S., et al., 2011. Good practice in healthcare for migrants: views and experiences of care professionals in 16 European countries. BMC Publ. Health 11, 187.

Schoevers, M., 2011. Hiding and Seeking": Health Problems and Problems in Accessing Healthcare of Undocumented Female Immigrants in The Netherlands. PhD thesis. Radboud University, Nijmegen.

Silove, D., Ventevogel, P., Rees, S., 2017. The contemporary refugee crisis: an overview of mental health challenges. World Psychiatr. 16 (2), 130-139.

Staring, R., Aarts, J., 2010. Jong en Illegaal in Nederland (Young and Illegal in The Netherlands) Boom Juridische Uitgevers: Den Haag.

Tilling, K., 2001. Capture-recapture methods-useful or misleading? Int. J. Epidemiol. 30 (1), 12-14.

Tilly, Charles, 2006. Why: what Happens when People Give Reasons...and Why. Princeton University Press, Princeton-Oxford.

Turner, V., 1969. The Ritual Process: Structure and Anti-structure. Cornell University Press, Ithaca-New York.

Van den Muijsenbergh, M., Schoevers, M., 2009. "Zorg voor ongedocumenteerden" Bijblijven 25 (4), 59-64.

Van der Heijden, P.G.M., Cruyff, M., Van Gils, G., 2015. Schattingen Illegaal in Nederland Verblijvende Vreemdelingen 2012 - 2013 (Estimate of Numbers of Undocumented in Netherlands 2012-13) Report Commissioned by Ministry of Justice and Security. Universiteit Utrecht, FSW, Utrecht, The Hague.

Van der Heijden, P.G.M., Cruyff, M., Van Gils, G., 2011. Schattingen Illegaal in Nederland Verblijvende Vreemdelingen 2009 (Estimate of Numbers of Undocumented in Netherlands in 2009) Report Commissioned by Ministry of Justice and Security. Universiteit Utrecht, FSW, Utrecht, The Hague.

Van der Heijden, P.G.M., Van Gils, G., Cruyff, M., Hessen, D., 2006. Een Schatting Van Het Aantal in Nederland Verblijvende Illegale Vreemdelingen in 2005 (Estimate of Numbers of Undocumented People in Netherlands in 2005), Report Commissioned by 
Ministry of Justice and Security. Universiteit Utrecht, FSW, Utrecht, The Hague. Van der Leun, J., Ilies, M., 2008. Undocumented Migration. Counting the Uncountable. Data and Trends across Europe, Country Report. Clandestino Research Project, European Commission, The Netherlands.

Van Ginneken, E., Gray, B., 2013. Coverage for undocumented migrants becomes more urgent. Ann. Intern. Med. 158 (5), 347-348.

Wudan, Y., 2016. Health: Only One Country Offers Universal Healthcare to All Migrants, National Public Radio, March 31. available at: https://www.npr.org/sections/ goatsandsoda/2016/03/31/469608931/only-one-country-offers-universal-healthcare-to-undocumented-migrants?t $=1535296365610$, Accessed date: 1 March 2019. 